ISSN $1978-3000$

\title{
Nilai Nutrisi Gulma Sawah Dominan di Kawasan Pesisir Kota Bengkulu
}

\author{
The Nutritive Value of Dominance Weeds on Paddy Field In Coastal Area of Bengkulu City \\ Sutriyono $^{1)}$, Nanik Setyowati ${ }^{2)}$, Hardi Prakoso ${ }^{1)}$, Agus Iswanrijanto ${ }^{2)}$, dan Eko Suprijono ${ }^{2)}$
}

\author{
1)Jurusan Peternakan Fakultas Pertanian Universitas Bengkulu \\ 2)Jurusan Budidaya Pertanian Fakultas Pertanian Universitas Bengkulu
}

\begin{abstract}
The research aimed to know the species weeds of rice, weed dominance, biomass production, and nutrition, on sawah ecosystem around pesisir was conducted at Kecamatan Sungai Serut Kota Bengkulu from May 2009 until July 2009. Fifty plots $1 \mathrm{~m} \times 1 \mathrm{~m}$ were used in the research. The weeds were harvested, than determine species of weed, the number of species and the number of individually of species, biomass production, nutritive value, dominance of each species, and its distribution. The result of research indicate that there are twenty three species of weed rice. Fymbristilis milliaceae, Lindernia anagalis, Cyperus halpan, Ludwigia perennis are weed of rice have high value of SDR that as : $18.30 \%, 11.92 \%, 10.82 \%, 8.94 \%, 7.55 \%$ and biomass production : $495.96 \mathrm{~kg} / \mathrm{ha}$ or $27.87 \%$, $206.2 \mathrm{~kg} / \mathrm{ha}$ or $11.15 \%, 127.9 \mathrm{~kg} / \mathrm{ha}$ or $7.19 \%, 94.08 \mathrm{~kg} / \mathrm{ha}$ or $5.29 \%$. The value of calcium are $0.02 \%, 0.09 \%$, $0.13 \%, 0.08 \%, 0.06 \%$, and the value of crude protein are $5.28 \%, 6.89 \%, 5.97 \%, 6.01 \%, 7,39 \%$ and the value of phosphor are $0.16 \%, 0.33 \%, 0.57 \%, 0.26 \%, 0.296 \%$. The dominant weeds are potentially as animal feed.
\end{abstract}

Key words: weeds species, sawah ecosystem, dominance, production and nutrition

\begin{abstract}
ABSTRAK
Penelitian bertujuan untuk memperoleh spesies-spesies gulma potensial sebagai sumber pakan ternak, berdasarkan pada produksi, dominansi, dan nilai nutrisi. Penelitian dilaksanakan di lahan sawah Kecamatan Sungai Serut, Kota Bengkulu. Dibuat petak sampel berukuran $1 \mathrm{~m}$ x $1 \mathrm{~m}$ sebanyak lima puluh petak sampel dengan metode jalur transek. Gulma dipanen dengan akarnya, kemudian dicuci, dipilah-pilahkan menurut jenisnya, dihitung jumlah jenis dan jumlah individu untuk setiap jenis, dihitung ditimbang, dianalisis kandungan nutrisinya (bahan kering, Protein kasar, kalsium, posfor) dan kandungan energi. Berdasarkan penelitian ditemukan 23 spesies gulma, dan lima jenis dominan adalah Gulma X (Ordo Poales), Fymbristilis milliaceae, Lindernia anagalis, Cyperus halpan, Ludwigia perennis, dengan nilai SDR berturut-turut adalah 18,30\%; $11,92 \% ; 10,82 \% ; 8,94 \% ; 7,55 \%$; produksi biomasa 495,96 kg/ha atau 27,87 \%; 206,2 kg/ha atau 11,15 \%, 127.9 $\mathrm{kg} / \mathrm{ha}$ atau $7,19 \%, 94.08 \mathrm{~kg} / \mathrm{ha}$ atau 5,29 \%. Kandungan protein 5,28 \%; 6,89 \%; 5,97\%; 6,01 \%; 7,39. Kandungan kalsium : 0,02 \%; 0,09 \%; 0,13 \%; 0,08 \%; 0,06 \%; kandungan posfor 0,16 \%; 0,33\%; 0.57\%; 0,26 \%; 0,296 \%. Seluruh gulma dominan menyebar secara berkelompok. Dapat disimpulkan bahwa gulma dominan mempunyai potensi sebagai sumber pakan.
\end{abstract}

Kata kunci : spesies, gulma sawah, dominansi, produksi, nutrisi

\section{PENDAHULUAN}

$$
\text { Dalam upaya meningkatkan }
$$

ketahanan pangan maka sektor peternakan mempunyai peranan yang cukup penting. Kenaikkan jumlah penduduk yang kian melonjak menuntut kenaikkan akan kebutuhan bahan pangan, baik nabati maupun hewani. Produksi pangan asal ternak perlu ditingkatkan. Salah satu kendala yang dihadapi adalah keterbatasan pakan akibat dari berbagai faktor seperti adanya persaingan konsumsi dengan manusia, penyempitan lahan pertanian, peningkatan populasi ternak, dan iklim. Pemanfaatan sumberdaya alam perlu 
seefisien mungkin dalam rangka meningkatkan ketahanan pangan. Sawah sebagai salah satu aset sumberdaya alam merupakan aset penting dalam penyediaan pakan ternak. Disamping limbah pertanian, dalam ekosistem sawah terdapat berbagai jenis flora, berupa gulma yang dapat dieksplorasi untuk peningkatan dan pengkayaan jenis pakan ternak.

Gulma merupakan jenis tumbuhan yang banyak tumbuh di persawahan yang sampai saat ini masih dianggap sebagai tanaman pengganggu (Trihaso, 2004). Disisi lain beberapa jenis gulma merupakan tumbuhan yang mengandung nutrisi dan dapat digunakan sebagai sumber pakan ternak, seperti Azolla (Achmanu dkk., 1997). Ternak unggas air seperti itik bersifat omnivora atau pemakan segala-galanya mulai dari umbiumbian, biji-bijian, rumput-rumputan, dan makanan yang berasal dari hewan atau binatang-binatang kecil (Suharno dan Amri, 1998, Setioko dkk., 2000). Selanjutnya dijelaskan bahwa itik mampu menekan pertumbuhan dan perkembangan keong mas dan produksi telur meningkat sampai $90 \%$. Peningkatan produksi disebabkan tercukupi nutrisi yang diperlukan ternak itik (Wasito dan Khairiah, 2004). Integrasi itik dan padi sawah dapat menurunkan kebutuhan pakan dan produksi itik meningkat (Mahfudz, dkk., 2004). Oleh sebab itu pemberantasan gulma dengan tidak ramah lingkungan dapat mengganggu kerusakan ekosistem dan penyebab rapuhnya ketahanan pangan. Dengan demikian gulma perlu dieksplorasi untuk digunakan sebagai sumber pakan.

Ada 33 jenis gulma yang sering dijumpai dan tumbuh pada pertanaman padi sawah, dengan perincian 10 jenis dari golongan rerumputan, 7 teki-tekian, dan 16 jenis gulma berdaun lebar (Sastroutomo, 1990). Dari berbagai jenis gulma tersebut tingkat kemampuan hidup dan berkembang biak berbeda antara satu dengan lainnya. Kemampuan hidup dan berkembang biak yang akan mendominasi kehidupan di persawahan sehingga produksinya tinggi. Perbedaan dalam individu gulma juga akan mempengaruhi sifat fisik dan komposisi kimia. Eksplorasi untuk memilih spesies gulma potensial sebagai sumber pakan perlu dilakukan dalam upaya meningkatkan ketersediaan pakan ternak. Tujuan penelitian adalah untuk mendapatkan jenis gulma potensial berdasarkan pada produksi, dominansi, dan nilai nutrisi. Manfaat penelitian adalah untuk pemanfaatan gulma sebagai pakan, konservasi, dan pengelolaan hijauan pakan khususnya tumbuhan sawah (gulma).

\section{MATERI DAN METODE}

Penelitian dilakukan dari bulan Maret sampai Mei 2009. Sampel gulma diambil di lahan sawah dalam kondisi bera di Kecamatan Sungai Serut Kota Bengkulu. Bahan dan alat yang digunakan adalah kantong plastik untuk tempat contoh gulma yang diambil, bilah bambu untuk membuat petak kuadrat berukuran $1 \mathrm{~m} \times 1$ $\mathrm{m}$, kawat kasa untuk tempat mencuci gulma, sabit, serta karung plastik sebagai tempat contoh gulma yang telah diambil. Dibuat petak pengamatan sebagai sampel dengan ukuran $1 \mathrm{~m}$ x $1 \mathrm{~m}$ sebanyak lima puluh petak dengan metode jalur transek. Gulma dipanen, dicuci, dipisahkan berdasarkan jenisnya kemudian diidentifikasi dengan cara mencocokkan dengan gambar dalam buku Weeds of Rice in Indonesia (Soerjani dkk., 1980), kemudian dihitung jumlah jenis dan jumlah individu. Gulma yang telah dikelompokkan sesuai jenisnya kemudian ditiriskan sampai air cucian hilang kemudian ditimbang untuk 
setiap jenisnya. Dari data yang diperoleh kemudian selanjutnya dihitung kerapatan nisbi, dominansi nisbi, frekuensi nisbi, dan Summed Dominance Ratio (SDR) (Triharso, 2004) dan penyebarannya menurut Ludwig and Reynold (1988). Kerapatan nisbi merupakan perbandingan kerapatan mutlak suatu spesies dengan kerapatan mutlak semua spesies yang dinyatakan dalam persen, dominansi nisbi merupakan perbandingan antara dominansi mutlak suatu spesies dengan dominansi mutlak seluruh spesies yang dinyatakan dalam persen, dan frekuensi nisbi merupakan perbandingan antara frekuensi mutlak suatu spesies dengan frekuensi mutlak semua spesies. Sedangkan SDR dihitung dengan rumus sebagai berikut :

$$
\mathrm{SDR}=\frac{\mathrm{KN}+\mathrm{DN}+\mathrm{FN}}{3} \times 100 \%
$$

Spesies yang mempunyai nilai SDR di atas nilai rata-rata golongan dinyatakan sebagai spesies yang dominan. Untuk mengetahui kandungan nutrisi (protein, energi dan mineral). maka diambil sampel gulma sejenis dari berbagai lokasi kemudian dikomposit. dan diambil sampel untuk dianalisis di Laboratorium.

\section{HASIL DAN PEMBAHASAN}

\section{Keanekaragaman dan Dominansi Gulma}

Beradsarkan pengamatan di lapangan gulma yang ditemukan di lahan persawahan pada periode bera ada 23 spesies yaitu : Lindernia anagalis. Lindernia crustaceae, gulma $X$ (Ordo Poales), Fymbristilis milliaceae, Cyperus halpan, Ludwigia perennis, Eleocharis artopurpurea, Hedyotis diffusa, Brachiaria paspaloides, Cyperus babakan, Monochoria vaginalis, Fuirena umbellata, Ischaenium rugosum,
Ludwigia hypsopifolia, Echinocloa colonum, Scirpus juncoides, Fymbristillis schoenoides, Fymbristillis globulosa, Cyperus kyllinga, Alternantera sisilis, Cyperus odoratus, Limnocharis flava, Cyperus compressus. Dari ke dua puluh tiga jenis tersebut gulma yang yang paling dominan adalah Gulma $X$ (Ordo Poales), diikuti dengan Fymbristilis milliaceae, Lindernia anagalis, Cyperus halpan, Ludwigia perennis, Brachiaria paspaloides, Fuirena umbellate, Ludwigia hypsopifolia, Eleocharis artopurpurea, Scirpus juncoides dengan nilai SDR (Summed Dominance Ratio) berturut-turut adalah : 18,30 \%; 11,92 \%; 10,82 \%; 8,94 \%; 7,55 \%; 6,05 \%; 5,60\%; $4,95 \% ; 3,39 \% ; 3,36 \%$.

\section{Produksi dan Nutrisi Biomasa Gulma}

Kandungan nutrisi dari berbagai spesies gulma dapat dilihat pada Tabel 2 . Kandungan protein tertinggi diperoleh pada Limnocharis flava yaitu 8,28 \% dengan kandungan nitrogen $(\mathrm{N})$ sebesar 1,32\% dari bahan kering, diikuti oleh Ludwigia perennis yang besarnya adalah 7,39\% dengan kandungan nitrogen 1,18\%, Monochoria vaginalis dengan kandungan protein kasar 7,12 \% dan kandungan nitrogen $1.14 \%$, Hedyotis difusa sebesar 7,08 $\%$ dengan kandungan nitrogen $1.13 \%$. Menurut Tillman dkk. (1986) bahwa protein tanaman berhubungan dengan aktivitas jaringan sehingga daun lebih banyak protein dibandingkan batang. Bila tanaman masak maka kadar protein kadar berkurang disebabkan rasio daun dan batang berkurang. Biji tanaman banyak mengandung protein, dan pada kebanyakan biji tanaman kadar protein lebih tinggi dari kadar protein seluruh tanaman. Selanjutnya dijelaskan juga bahwa pada beberapa tanaman, waktu menurunnya kadar protein dengan semakin tuanya umur tanaman lebih lambat dibandingkan tanaman lain. Pada penelitian ini jenis gulma berdaun lebar dan sempit proporsi daunnya sangat tinggi 
ISSN $1978-3000$

Tabel 1. Nilai Energi beberapa Spesies Gulma

\begin{tabular}{ll}
\hline Spesies Gulma & Kalori/kg Bahan Kering \\
\hline Lindernia anagalis & 3358,19 \\
Ludwigia perennis & 4009,33 \\
Fymbristilis milliaceae & 3166,82 \\
Cyperus halpan & 4244,83 \\
Gulma X (Ordo Poales) & 3439,57 \\
\hline Rataan & 3643,75 \\
\hline Sumber : Hasil analisis di Laboratorium Peternakan Fakult
\end{tabular}

Sumber : Hasil analisis di Laboratorium Peternakan Fakultas Pertanian Universitas Bengkulu.(2009)

dan kondisi batang yang lunak dengan kadar air yang tinggi.

Kandungan mineral $\mathrm{Ca}$ pada umumnya rendah. Kandungan posfor $(\mathrm{P})$ tertinggi diperoleh pada spesies gulma Limnocharis flava, diikuti oleh Lindernia anagalis, Cyperus babakan, Monochoria vaginalis, dan Alternantera sisilis, yang besarnya berturut-turut adalah 0,58 \%; 0,57 $\%$; 0,56 \%; 0,36\%; dan 0,34\%. Tillman dkk. (1986) mengemukakan bahwa kadar mineral dalam tanaman adalah sangat variabel tergantung spesies tanaman dan bagian tanaman. Kalsium dan posfor adalah unsur-unsur makanan yang penting dalam makanan ternak karena kedua unsur ini menyusun $70 \%$ abu tubuh hewan. Jenis-jenis leguminosa kaya akan kalsium sedangkan tanaman lain mengandung kalsium lebih sedikit. Kalsium berhubungan dengan fungsi vegetatif dari bagian tanaman, sehingga daun mengandung kalsium lebih banyak dibanding batang. Sebaliknya, biji selalu mengandung kalsium lebih sedikit bagianbagian tanaman lainnya; namun demikian, biji yang mengandung minyak lebih banyak mengandung kalsium dibanding biji lain. Sedangkan posfor dikandung lebih banyak dalam biji dibandingkan dengan tanaman lainnya, tetapi daun seperti halnya kalsium, lebih banyak mengandung posfor dari pada batang. Kalsium dan posfor dalam bagian tanaman vegetatif sangat dipengaruhi oleh keberadaan tanah dan faktor-faktor lainnya.

Produksi biomasa gulma secara total adalah 1779,6 kg/ha bahan segar atau $361,15 \mathrm{~kg} / \mathrm{ha}$. bahan kering. Produksi tersebut terdiri atas campuran berbagai jenis gulma. Kelompok lima jenis gulma dengan SDR terbesar atau lima spesies gulma dominan memberikan kontribusi produksi biomasa sebesar 55,42 \%; dengan perincian sebagai berikut Gulma X (Ordo Poales) 495,96 kg/ha atau 27,87 \%; Fymbristilis milliaceae $206.2 \mathrm{~kg} / \mathrm{ha}$ atau 11,15 $\%$, Cyperus halpan $127.9 \mathrm{~kg} / \mathrm{ha}$ atau 7,19\% , Lindernia anagalis 94,08 kg/ha atau 5,29\%. Sisanya 44,58 \% merupakan produksi biomasa oleh spesies lain. Sedangkan untuk produksi bahan kering lima gulma dominan memberikan kontribusi sebesar $56,33 \%$, dan sisanya 53,67 \% merupakan produksi bahan kering biomasa spesies yang lain yang ditemukan.

Biomasa gulma sawah juga mempunyai arti penting sebagai sumber protein bagi ternak. Rata-rata produksi protein per hektar lahan sawah di lakasi penelitian adalah 19016,44 gram per hektar atau 19,019 $\mathrm{kg}$ per hektar. Dari nilai tersebut 5 spesies gulma dominan memberikan kontribusi sebesar 42,22 \% dengan perincian : Gulma X (Ordo Poales) 6,74 \%; Fymbristilis milliaceae 3,85 \%, Cyperus halpan $0.68 \%$, Lindernia anagalis $23,28 \%$, dan Ludwigia perennis 7,67 \%. 
ISSN $1978-3000$

Tabel 2. Kandungan Nutrisi Berbagai Spesies Gulma

\begin{tabular}{|c|c|c|c|c|c|}
\hline \multirow[b]{2}{*}{ JENIS GULMA } & \multirow{2}{*}{$\begin{array}{c}\text { Bahan } \\
\text { Kering } \\
(\%)\end{array}$} & \multicolumn{4}{|c|}{ Dasar Bahan Kering } \\
\hline & & $\mathrm{N}(\%)$ & PK (\%) & $\mathrm{Ca}(\%)$ & $\mathrm{P}(\%)$ \\
\hline Lindernia anagalis & 22,84 & 0,95 & 5,97 & 0,13 & 0,57 \\
\hline Ludwigia hypsopifolia & 23,89 & 1,04 & 6,52 & 0,08 & 0,31 \\
\hline Gulma X (Ordo Poales) & 16,89 & 0,85 & 5,28 & 0,02 & 0,16 \\
\hline Hedyotis diffusa & 19,39 & 1,13 & 7,08 & 0,09 & 0,20 \\
\hline Ludwigia perennis & 31,78 & 1,18 & 7,39 & 0,06 & 0,296 \\
\hline Fuirena umbellata & 20,86 & 0,94 & 5,88 & 0,08 & 0,34 \\
\hline Fymbristilis milliaceae & 22,73 & 1,10 & 6,89 & 0,09 & 0,33 \\
\hline Fymbristillis schoenoides & 14,71 & 0,67 & 4,19 & 0,07 & 0,18 \\
\hline Echinocloa colonum & 14,78 & 0,68 & 4,23 & 0,05 & 0,22 \\
\hline Cyperus babakan & 26,51 & 0,97 & 6,08 & 0,07 & 0,56 \\
\hline Alternantera sisilis & 17,22 & 0,87 & 5,46 & 0,06 & 0,34 \\
\hline Limnocharis flava & 15,79 & 1,32 & 8,28 & 0,04 & 0,58 \\
\hline Scirpus juncoides & 20,55 & 0,98 & 6,14 & 0,05 & 0,20 \\
\hline Monochoria vaginalis & 19,18 & 1,14 & 7,12 & 0,13 & 0,36 \\
\hline Cyperus halpan & 24,68 & 0,96 & 6,01 & 0,08 & 0,26 \\
\hline Eleocharis artopurpurea & 15,34 & 0,56 & 3,53 & 0,04 & 0,21 \\
\hline Lindernia crustaceae & 17,73 & 1,06 & 6,64 & 0,04 & 0,26 \\
\hline
\end{tabular}

Sumber: Hasil analisis Laboratorium Ilmu Tanah Fakultas Pertanian Universitas Bengkulu (2009)

Biomasa gulma juga mengandung energi yang nilai berbeda antara satu spesies dengan spesies lainnya. Pada gulma dominan nilai energi dapat dilihat pada Tabel 1.

Pada Tabel 1 ditunjukkan bahwa rata-rata kandungan energi pada lima jenis gulma dominan adalah $3643,75 \mathrm{kal} / \mathrm{kg}$ bahan kering. Nilai tersebut lebih tinggi jika dibandingkan dengan kandungan energi jagung (DE)yang besarnya adalah $3540 \mathrm{kal} / \mathrm{kg}$ bahan kering (Hartadi dkk., 1990).

Nilai energi tertinggi diperoleh pada Cyperus halpan, yang besarnya adalah 4244,83 cal $/ \mathrm{kg}$, diikuti dengan Ludwigia perennis. Gulma X (Ordo Poales), Lindernia anagalis, dan Fymbristilis milliaceae yang besarnya berturut-turut adalah 4009,33 cal $/ \mathrm{kg}$, $3439,57 \mathrm{cal} / \mathrm{kg}, \quad 3358,19 \mathrm{cal} / \mathrm{kg}, \quad 3166,82$ cal/kg. Tillman dkk. (1986) mengemukakan bahwa dalam produksi tanaman kecuali biji yang mengandung minyak, karbohidrat merupakan bagian yang sangat penting. Bentuk karbohidrat dalam tanaman berbeda-beda menurut fungsinya. Dalam biji, karbohidrat terutama dalam bentuk pati yang menjadi cadangan energi, sedangkan dalam batang dan sedikit dalam daun, karbohidrat berfungsi sebagai komponen penyangga yang terdiri lebih banyak dari selulosa yang menjadi dasar kerangka karbohidrat. Dalam penelitian ini nilai tertinggi Energi diperoleh pada jenis gulma Cyperus halpan. Hal ini dimungkinkan karena adanya biji-biji gulma yang merupakan simpanan karbohidrat.

\section{SIMPULAN}

Berdasarkan penelitian di kecamatan sungai serut kota Bengkulu ditemukan 23 spesies gulma, dan lima jenis dominan adalah Gulma X (Ordo Poales), Fymbristilis milliaceae, Lindernia anagalis, Cyperus halpan, dan Ludwigia perennis, dengan nilai SDR berturut-turut adalah 18,30 \%; 11,92 \%; $10,82 \% ; 8,94 \% ; 7,55 \%$; dengan produksi biomasa berturut-turut adalah 495,96 kg/ha atau $27,87 \%$; $206.2 \mathrm{~kg} / \mathrm{ha}$ atau $11,15 \%$, $127.9 \mathrm{~kg} / \mathrm{ha}$ atau $7,19 \%, 4.08 \mathrm{~kg} / \mathrm{ha}$ atau 
$5,29 \%$. Kandungan protein berturut-turut adalah 5,28 \%; 6,89 \%; 5,97\%; 6,01 \%; 7,39.

Kandungan kalsium berturutturut adalah : 0,02 \%; 0,09\%; 0,13\%; 0,08 $\% ; 0,06 \%$; dan kandungan posfor berturutturut adalah : $0,16 \% ; 0,33 \% ; 0.57 \% ; 0,26 \%$; $0,296 \%$.

\section{DAFTAR PUSTAKA}

Abduh, U., A. Ella, dan A. Nurhayu. 2004. Integrasi Ternak Itik Dengan Sistem Usaha Tani Berbasis Padi di Kabupaten Sidrap Sulawesi Selatan. Sistem Integrasi Tanaman-Ternak. Pusat Penelitian Pengembangan Peternakan Bekerjasama dengan Balai Pengkajian Teknologi Pertanian Bali (BPTP Bali) dan Crop Animal System Research Network (CASREN).

Achmanu, Rahardjo, Koentjoko, Susanto. 1997. Pengaruh Tingkat Azolla dan Enzim Pertumbuhan Dalam Ransum Terhadap Performans Itik Jantan. Agrivita Vol.20 No.2.2103108.

Haryatun. 2008. Teknik identifikasi jenis gulma dominan dan status ketersedlaan hara Nitrogen, fosfor, dan kalium beberapa jenis gulma Di lahan rawa lebak. Buletin Teknik Pertanian Vol. 13 No. 1. Hal :19-22.

Mahfudz, L.D., W. Sarengat, S.M. Ardiningsari, E. Supriatna dan B. Srigandono. 2004. Pemeliharaan sistem terpadu dengan tanaman padi terhadap performans dan kualitas karkas itik lokal jantan umur 10 minggu. Sistem Integrasi Tanaman-Ternak. Pusat Penelitian Pengembangan Peternakan
Bekerjasama dengan Balai Pengkajian Teknologi Pertanian Bali (BPTP Bali) dan Crop Animal System Research Network (CASREN).

Pool, R.W. 1974. An Introduction to Quantitative Ecology. McGraw-Hill Book Company. New York.

Sastroutomo.1990. Ekologi Gulma. Cetakan Pertama. PT. Gramedia Pustaka Utama. Jakarta.

Setioko, A.R., S. Iskandar, Y.C. Rahardjo, T.D. Sudjana, T. Murtisari, M. Purba, S.E. Estuningsih, N. Sunandar, dan D. Pramono. 2000. Model usaha ternak itik dalam sistem pertanian dengan indek pertanaman padi tiga kali per tahun (IP Padi 300) : 1. Pengaruh timbal balik antara peternak dan petani. Jurnal Ilmu Ternak dan Veteriner. Vol 5 (1) : 38-45.

Suharno, B. dan K. Amri. 1998. Beternak Itik Secara Intensif. Penebar Swadaya. Jakarta.

Tillman. A.D., H. Hartadi, S. Reksohadiprodjo, S. Prawirokusumo, S. Lebdosukojo. 1986. Ilmu Makanan Ternak Dasar. Gadjah Mada University Press.

Triharso. 2004. Dasar-dasar Perlindungan Tanaman. Gadjah Mada University Press.

Warsito dan Hairiah. 2004. Peranan Itik dalam Mengendalikan Keong Mas di Sawah Irigasi di Sumatra Utara. Sistem Integrasi Tanaman-Ternak. Pusat Penelitian Pengembangan Peternakan Bekerjasama dengan Balai Pengkajian Teknologi Pertanian Bali (BPTP Bali) dan Crop Animal System Research Network (CASREN). 